\title{
In Vitro Somatic Embryos Multiplication of Eurycoma longifolia Jack using Temporary Immersion System RITA ${ }^{\circledR}$ \\ (Multiplikasi In Vitro Embrio Somatik daripada Eurycoma longifolia Jack Menggunakan Sistem Rendaman Sementara RITA ${ }^{\circledR}$ )
}

\author{
NOOR MADIHAH MOHD, HAFSAH JA’AFAR, DHIYA DALILA ZAWAWI \& NADIAWATI AliaS*
}

\begin{abstract}
Temporary immersion system, Recipient for Automated Temporary Immersion ${ }^{\circledR}\left(\right.$ RITA $\left.^{\circledR}\right)$, is one of the innovative systems that allow the production of large number of somatic embryos or plantlets via in vitro plant propagation. It has been widely used to avoid as sociated problems such as low multiplication rate of somatic embryos and hyperhydricity during plant propagation. Thus, an attempt was made to investigate optimal parameters such as immersion time and immersion frequency, for the multiplication of direct somatic embryogenesis from cotyledon culture of Eurycoma longifolia Jack using RITA $^{\circledR}$. Four periods of immersion time $(1,5,10$ and 15 min every $4 \mathrm{~h})$ were evaluated for the efficiency in somatic embryos multiplication. In order to optimize repetitive somatic embryogenesis, three different immersion frequencies $(5$ min immersion every 2, 4 and 8 h) were applied. The highest number of secondary embryos (69.67 \pm 9.73$)$ was found significant when immersing the globular, primary embryos for 5 min every $4 \mathrm{~h}$ as compared to other immersion time tested. The secondary somatic embryos obtained in this study could be further used for the development of plantlet regeneration of $\mathrm{E}$. longifolia.
\end{abstract}

Keywords: Eurycoma longifolia Jack; secondary embryogenesis; temporary immersion system RITA

\section{ABSTRAK}

Sistem rendaman sementara, 'Recipient for Automated Temporary Immersion ${ }^{\circledR}$ ' $\left(\right.$ RITA $\left.^{\circledR}\right)$, merupakan salah satu sistem inovatifyang merangsang pengeluaran embrio somatik atau anak pokok dalam kuantiti yang banyak bagi pembiakbakaan in vitro pokok. Sistem ini telah banyak digunakan bagi mengelakkan masalah seperti multiplikasi embrio somatik yang rendah dan hiperhidrisiti bagi pembiakbakaan secara in vitro. Jadi, satu kajian telah dijalankan bagi mengkaji parameter yang optimum seperti tempoh masa dan frekuensi rendaman bagi multiplikasi embrio somatik daripada kultur kotiledon Eurycoma longifolia Jack dengan menggunakan RITA $^{\circledR}$. Empat tempoh masa rendaman (1, 5, 10 dan 15 min setiap 4 jam) telah dinilai keberkesanannya bagi multiplikasi embrio somatik. Untuk mengoptimumkan penghasilan embrio somatik sekunder, tiga frekuensi rendaman (5 min setiap 2, 4 dan 8 jam) telah digunakan. Jumlah embrio sekunder somatik tertinggi (69.67 \pm 9.73$)$ telah diperoleh untuk tempoh rendaman selama 5 min bagi setiap 4 jam jika dibandingkan dengan tempoh masa rendaman yang lain. Embrio somatik sekunder yang diperoleh melalui kajian ini boleh digunakan pada masa hadapan bagi pertumbuhan semula anak pokok E. longifolia.

Kata kunci: Embrio somatik sekunder; Eurycoma longifolia Jack; sistem rendaman sementara RITA ${ }^{\circledR}$

\section{INTRODUCTION}

Eurycoma longifolia Jack, also known as Tongkat Ali is considered one of the most promising herb species in South East Asia due to its medicinal properties. This plant is also one of the priority herbs identified by Government of Malaysia in National Key Economic Areas (NKEAs) proprietary list and the Malaysian herbal market turnover is estimated to be around USD 2.5 Billion in 2007 (Radhakrishnan \& Safinar 2015). In view of its commercial value, many scientific studies have been carried out for its propagation (Keng et al. 2002) and its biological activity such as antioxidant (Varghese et al. 2013), antiinflammatory (Varghese et al. 2013), anti-proliferative (Wong et al. 2012), anti-malaria (Basir et al. 2012), antitoxoplasma (Kavitha et al. 2012), anti-tumor (Al-Salahi et al. 2014), hepatoprotective activity (Panjaitan et al. 2013), cytotoxic activity (Hajjouli et al. 2014; Kuo et al. 2004; Li et al. 2013; Zakaria et al. 2009) and adaptogenic properties (Talbott et al. 2013). Other than that, seed and somatic embryos histology (Balakrishnan et al. 2014; Danial et al. 2011) and secondary metabolites (Chua et al. 2011; Keng et al. 2010; Khari et al. 2014) of this plant had been published.

Despite its commercial value, conventional propagation of this plant is constrained due to its low rate of seed production and germination, seasonal flowering pattern, loss of genetic diversity, local extinctions and habitat degradation (Balakrishnan et al. 2014; Canter et al. 2005; Hussein et al. 2005). In addition, excessive harvesting; via obtaining the active compounds from the 
roots to fulfill the increasing demand for pharmaceutical, herbal and its by-products would lead to serious shortage of this plant in the wild. This serious shortage also may result from over-exploitation by medicinal plant collectors without proper conservative action taken (Ling et al. 2010).

Generally, in most woody plants, the selection of the elite plants is possible at the adult phases where they show their phenotypic characteristics. However, cloning the adult plants is not simple and sometimes only possible at certain young stages (Hernández et al. 2011). Thus, somatic embryogenesis is studied to allow the production of uniform and genetically identical plants to the elite mother clones. Micropropagation technique on semi solid medium have been used for many in vitro cultures, however, the usage of liquid medium for somatic embryogenesis and plantlet establishment could reduce production costs and allow the automation of cultures (Jimenez et al. 1999). Besides that, liquid culture also offers more uniform culture conditions, reduced space and usage of large containers (Jimenez et al. 1999). However, one of the drawbacks of the liquid culture is hyperhydricity, that may resulted from the continuous exposure to the liquid media (Etienne \& Berthouly 2002).

Temporary immersion system (TIS) is one of the innovative, automated system that allow adequate mixing of culture nutrients and avoid continuous immersion which providing better aeration to the explants (Etienne \& Berthouly 2002). The advantages of this system are well established and defined in many research papers (Etienne \& Berthouly 2002; Roels et al. 2005) such as improves traditional procedure, overcoming hyperhydricity, allow partial automation of cultures, allows uniform contact between explants and culture medium and reduce the production cost. The RITA $^{\circledR}$ system that introduced by Teisson and Alvard (1999) had been used for the multiplication of somatic embryos of Coffea arabica (Albarran et al.2005) and shoot multiplication in Quercus alba (Pérez et al. 2013).

Propagation via in vitro studies of E. longifolia have been achieved previously through indirect somatic embryogenesis (Hussein et al. 2005) and axillary shoot multiplication (Hassan et al. 2012), however, there are limited reports on the usage of RITA $^{\circledR}$ as the alternative methods for the mass propagation of E. longifolia in vitro. Thus, the aim of this study was to evaluate the efficiency of RITA ${ }^{\circledR}$ for secondary somatic embryogenesis, focusing on the effects of duration immersion time and immersion frequencies on the multiplication of secondary embryogenesis and comparison to the semi solid medium.

\section{MATERIALS AND METHODS}

\section{PLANT MATERIALS AND DIRECT SOMATIC} EMBRYOGENESIS INDUCTION

E. longifolia seeds in a bunch consisting more than 100 seeds were chosen as our initial explants as shown in
Figure 1(a). Seeds of E. longifolia were collected from the herbal garden in the Museum of Terengganu from early July to September 2014 during the period of fruit development (Figure 1(b)). Seeds were surface-sterilized by using Teepol and rinsed with distilled water before transferred into laminar air flow. Then, the seeds were sterilized with $70 \%$ ethanol for one min before immersing them for another $20 \mathrm{~min}$ in $20 \%$ Clorox $^{\circledR}$ containing two drops of Tween 20, followed by three rinses in sterile distilled water. The seeds were cut vertically into two parts, showing two lobes of cotyledons (Figure 1(c)). The immature zygotic embryos were removed and the cotyledons were excised horizontally into three parts and cultured under sterile conditions (Figure 1(d) and 1(e)).

Direct somatic embryogenesis induction was performed according to Zawawi et al. (2015): Isolated cotyledon explants were cultured on modified Murashige and Skoog medium (Murashige \& Skoog 1962) containing $3 \%(\mathrm{w} / \mathrm{v})$ sucrose, solidified with $2.5 \%(\mathrm{w} / \mathrm{v})$ phytagel (Duchefa) and supplemented with $0.2 \mathrm{mg} / \mathrm{L}$ IBA (Duchefa). Culture media were adjusted to $\mathrm{pH} 5.7$ \pm 0.1 and sterilized for $15 \mathrm{~min}$ under the pressure of 1 $\mathrm{kg} \mathrm{cm}{ }^{-2}$ at $121^{\circ} \mathrm{C}$. About $0.1 \mathrm{mg} / \mathrm{L}$ Zeatin (Duchefa) and $0.12 \mathrm{mg} / \mathrm{L}$ TDZ (Duchefa) were filter sterilized (0.22 $\mu \mathrm{m})$ before added to the sterile medium. About $20 \mathrm{~mL}$ of culture medium was poured into each petri dish $(8 \mathrm{~cm}$ in diameter). All cultures were maintained in a walk-in growth chamber under complete darkness at $25 \pm 2^{\circ} \mathrm{C}$ for two months. The six weeks old globular somatic embryos (Figure 1(f)) were carefully detached from the cotyledons explants and proceed for the secondary embryogenesis experiment.

\section{TEMPORARY IMMERSION SYSTEM (TIS) AND CULTURE CONDITIONS}

Temporary immersion systems were used after the somatic embryogenesis induction phase. They were applied in RITA ${ }^{\circledR}$ bioreactors $(15 \times 13 \mathrm{~cm}, 1 \mathrm{~L}$ volume $)$ with $150 \mathrm{~mL}$ of liquid medium. RITA ${ }^{\circledR}$ bioreactors composed of two separate parts, the upper part is for the somatic embryos material and the lower part is for the liquid modified MS medium. The systems were controlled by a timer set which had been regulated according to the immersion time or immersion frequencies. The effects of semi solid medium using petri dish and liquid medium by RITA $^{\circledR}$ bioreactors on secondary somatic embryogenesis were compared.

Four periods of immersion time $(1,5,10$ and $15 \mathrm{~min}$ every $4 \mathrm{~h}$ ) were evaluated for the efficiency in somatic embryos multiplication. Following the determination of the optimum immersion time, the effects of different immersion frequencies ( 5 min immersion every 2,4 and $8 \mathrm{~h}$ ) were studied after one month of culture incubation. For both experiments, 15 uniform-sized globularstage somatic embryos were employed for semi solid experiment and for RITA ${ }^{\circledR}$ bioreactors. The culture media used in this secondary embryogenesis experiment was 


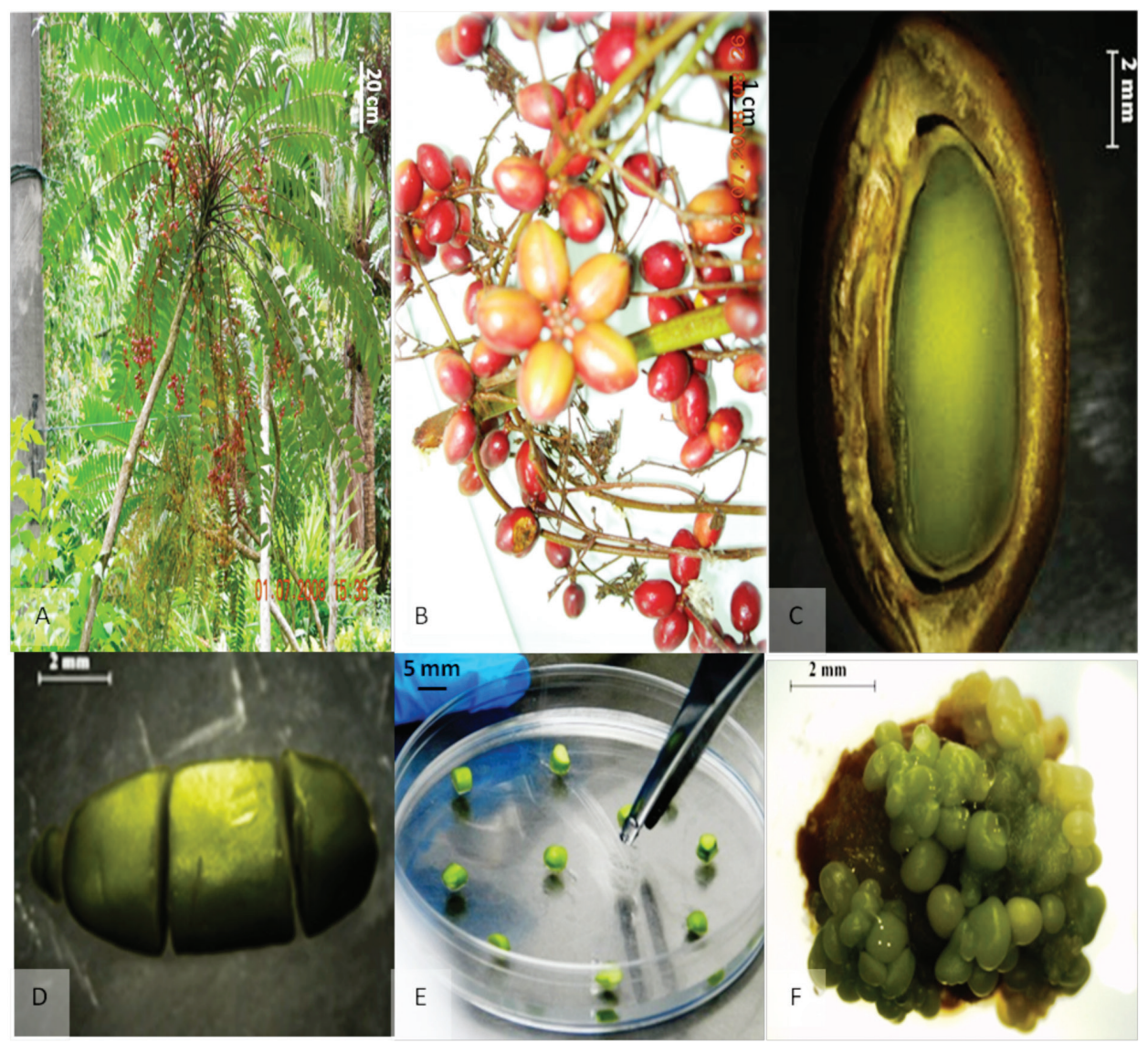

FIGURE 1. Culture establishment of E. longifolia. a) Mother plant at Museum of Terengganu; b) Close-up mature, ovoid seeds of E. longifolia; c) Vertical cross-section seed showing big cotyledon; d) Dissected cotyledon into 2 - 3 mm thick segments cultured; e) Cotyledon explants culture on Modified MS medium and f) Direct, globular somatic embryos used as the explants in both semi solid and RITA $^{\circledR}$ bioreactors

Modified MS media supplemented with $0.2 \mathrm{mg} / \mathrm{L}$ IBA, $0.1 \mathrm{mg} / \mathrm{L}$ Zeatin, $0.12 \mathrm{mg} / \mathrm{L}$ TDZ and $0.1 \mathrm{~g} / \mathrm{L}$ activated charcoal (AC). All experiments were carried out in 4 replicates.

\section{STATISTICAL ANALYSIS}

The experiments were set up in a completely randomized design with four replicates for each treatment and each replicate had fifteen explants. The experiments were repeated twice. After one month of culture incubation, numbers of secondary somatic embryos were counted for both semi solid medium (control) and in RITA ${ }^{\circledR}$. Data were analyzed using statistical program SPSS (SPSS Inc., USA) version 17. Differences between treatments were contrasted by one-way analysis of variance (ANOVA). While, post hoc multiple comparisons were carried out using Tukey test at a significant level of $p<0.05$.

\section{RESULTS AND DISCUSSION}

In vitro plant production through shoot multiplication (Gatica-Arias \& Weber 2013; Pérez et al. 2013; Wilken et al. 2014) and somatic embryogenesis multiplication (Albarran et al. 2005; Etienne \& Berthouly 2002;
Niemenak et al. 2008) by using RITA $^{\circledR}$ have been well documented. According to Paek et al. (2005), liquid culture has been used to facilitate plantlets and multiplication of somatic embryos of Panax ginseng, however, it had been reported lead to other problems to the explants such as asphyxia (Watt 2012), hyperhydricity (Albarran et al. 2005; Niemenak et al. 2008; Teisson \& Alvard 1999) and vitrification (Teisson \& Alvard 1999).

Thus, bioreactor especially RITA $^{\circledR}$ is one of the alternative strategy that had been employed to tackle the problems arise. It allows gentle ventilation of the air in the bioreactor, resulting the sufficient mixing and uniform sequential changing of culture liquid medium (Albarran et al. 2005; Etienne \& Berthouly 2002; Pérez et al. 2013; Teisson \& Alvard 1999). There was also no shoot tip necrosis (STN) symptom observed from the shoots sprouted in RITA ${ }^{\circledR}$ as compared to semi solid MS medium in pistachio micropropagation (Akdemir et al. 2014).

Parameters such as duration of immersion time (Akdemir et al. 2014), immersion frequency (Akdemir et al. 2014; Mallón et al. 2011; Pérez et al. 2013; Polzin et al. 2014), inoculum density (Pérez et al. 2013; Polzin et al. 2014), inoculum type (Pérez et al. 2013) and volume of the container (Teisson \& Alvard 1999) in RITA ${ }^{\circledR}$ have 
also been studied previously by various researcher. For this paper, different periods of immersion time were tested both in RITA ${ }^{\circledR}$ and on semi solid medium. In this experiment, one-way analysis of variance (ANOVA) showed that 5 min immersion time for every $4 \mathrm{~h}$ in RITA ${ }^{\circledR}$ was found to give the highest $(69.6 \pm 9.7)$ multiplication of secondary somatic embryos of E. longifolia significantly. While, longer periods of immersion time, 10 and $15 \mathrm{~min}$ for every $4 \mathrm{~h}$, did not increase number of secondary somatic embryos multiplication which were $40.6 \pm 3.5$ and $38.3 \pm$ 1.2, respectively (Figure 2).

Moreover, $1 \mathrm{~min}$ immersion every $4 \mathrm{~h}$ gave the lowest multiplication of secondary somatic embryos of E. longifolia $(22.3 \pm 1.4)$ as compared to other treatments tested (Figure 2). This might be due to short duration time in immersing the somatic embryo explants. However, this finding was found in contrast with a study carried out by Pérez et al. (2013). Perez et al. (2013) has found that 1 min immersion time for every 4 and $6 \mathrm{~h}$ have significantly increased the fresh weight of the cork oak, Quercus alba somatic embryogenesis proliferation. Another study by Niemenak et al. (2008) on Theobroma cacao has found out that $1 \mathrm{~min}$ immersion time for every $6 \mathrm{~h}$ per day managed to increase production of somatic embryos up to 13 - fold after three months of culture incubation. He is also stated that conversions of somatic embryos into torpedo shaped forms were also observed. Teisson and Alvard (1999) also stated that higher frequency of short immersions time was found to stimulate embryo production. These studies showed that each species need their own optimum condition and need to be studied separately as suggested by Akdemir et al. (2014)

Based on our findings, secondary somatic embryos in semi solid medium have small number of multiplication $(26.6 \pm 7.2)$ as compared to the explants immersed in RITA $^{\circledR}$ bioreactor (Figure 2). Guan and De Klerk (2000)

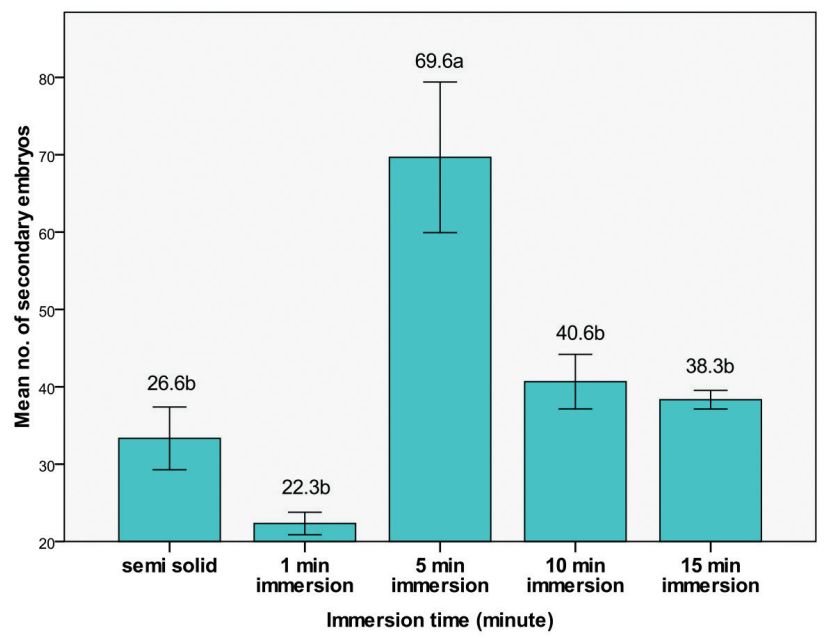

FIGURE 2. Effect of different immersion times on temporary immersion system RITA ${ }^{\circledR}$ and semi solid medium on secondary somatic embryogenesis of E. longifolia after one month of culture incubation

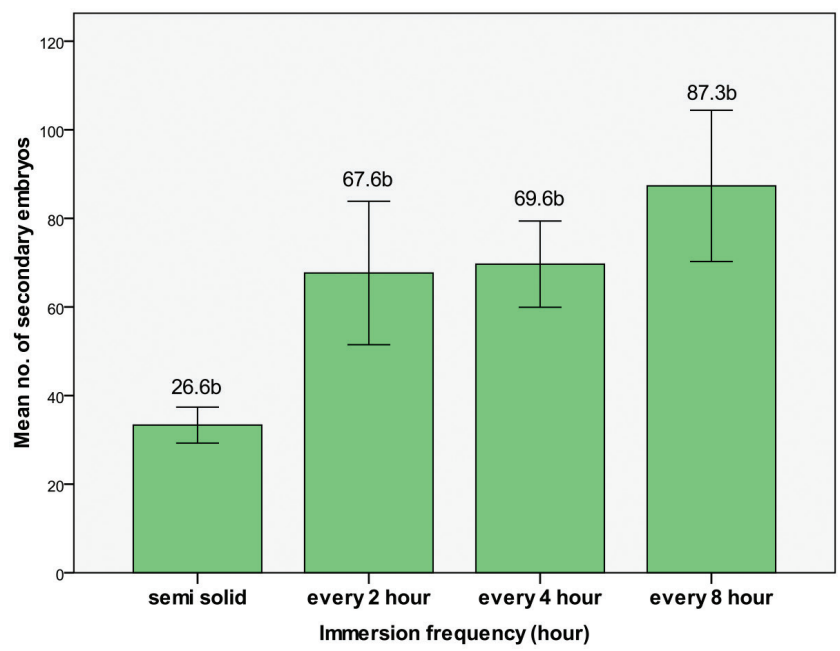

FIGURE 3. Effect of different immersion frequencies on temporary immersion system RITA ${ }^{\circledR}$ and semi solid medium on secondary somatic embryogenesis of E. longifolia after one month of culture incubation 
reported that in semi solid medium, shoots explants absorb nutrients through their cut end and nutrients are transferred by water flows in xylem and phloem and not through stomata. Nutrients from the medium components translocate better in a liquid medium since it went through stomata and aqueous pores (Schönherr 2006). This will be taken up better by plants when undergo shorter distanced growing regions as stated by De Klerk and Ter Brugge (2011). This theory would suggest that RITA ${ }^{\circledR}$ bioreactor system managed to promote higher explants proliferation as compared to the semi solid medium.

Next, for the second experiment, about 60 primary somatic embryos were used to study the effect of different immersion frequencies $(2,4$, and $8 \mathrm{~h})$ by using RITA $^{\circledR}$ bioreactor. For immersion time, 5 min immersion time was used in this experiment since it was identified as the most efficient immersion time during the first part of the experiment. The result from the experiment conducted showed no significant difference after further optimizations were carried out (Figure 3). From this experiment, $5 \mathrm{~min}$ immersion time for every $8 \mathrm{~h}$ showed the highest number of secondary somatic embryos multiplication $(87.3 \pm 17.0)$ as compared to the other frequencies tested (Figure 3). Vitrified shoots were also found reduced in conjunct to the increased frequency hour from 8 to $16 \mathrm{~h}$ in the RITA ${ }^{\circledR}$ bioreactor system as supported by Akdemir et al. (2014).

\section{CONCLUSION}

The findings from the present study demonstrated that RITA $^{\circledR}$ could be used to increase multiplication of secondary somatic embryos of E. longifolia as compared to semi solid medium. The result obtained showed that $5 \mathrm{~min}$ immersion time every $8 \mathrm{~h}$ gave the highest number $(87.3 \pm 17.0)$ of secondary somatic embryos of E. longifolia compared to other treatments tested. However, other parameters such as culture type and initial amount of inoculum can also be studied using RITA ${ }^{\circledR}$ in order to optimize multiplication of secondary embryogenesis of E. longifolia in vitro.

\section{ACKNOWLEDGEMENTS}

This research was financially supported by grant (UniSZA/11/GU/21) and the seed explants generously obtained from Lembaga Muzium Negeri Terengganu.

\section{REFERENCES}

Akdemir, H., Süzerer, V., Onay, A., Tilkat, E., Ersali, Y. \& Çiftçi, Y.O. 2014. Micropropagation of the pistachio and its rootstocks by temporary immersion system. Plant Cell, Tissue and Organ Culture 117(1): 65-76.

Albarran, J., Bertrand, B., Lartaud, M. \& Etienne, H. 2005. Cycle characteristics in a temporary immersion bioreactor affect regeneration, morphology, water and mineral status of Coffee (Coffea arabica) somatic embryos. Plant Cell, Tissue and Organ Culture 81: 27-36.

Al-Salahi, O.S.A., Ji, D., Majid, A.M.S.A., Kit-Lam, C., Abdullah, W.Z., Zaki, A., Din, S.K.K.J., Yusoff, N.M.
\& Majid, A.S.A. 2014. Anti-tumor activity of Eurycoma longifolia root extracts against K-562 cell line: In vitro and in vivo study. PloS One 9(1): e83818.

Balakrishnan, B., Alwee, S.S.R.S., Keng, C.L. \& Subramaniam, S. 2014. Histology of somatic embryos of Eurycoma longifolia (Simaroubaceae): Relevance in Agrobacterium rhizogenes-mediated transformation. Pakistan Journal of Botany 46(3): 1061-1064.

Basir, R., Chan, K.L., Yam, M.F., Othman, F., Abdullah, W.O., Moklas, M.A.M., Rahim, A.S.A., Ismail, I.S., Hidayat, M.T., Taib, C.N.M. \& Mahmus, R. 2012. Antimalarial activity of selected Malaysian medicinal plants. Phytopharmacology 3(1): 82-92.

Canter, P.H., Thomas, H. \& Ernst, E. 2005. Bringing medicinal plants into cultivation: Opportunities and challenges for biotechnology. Trends in Biotechnology 23(4): 180-185.

Chua, L.S., Amin, N.A.M., Neo, J.C.H., Lee, T.H., Lee, C.T., Sarmidi, M.R. \& Aziz, R.A. 2011. LC-MS/MS-based metabolites of Eurycoma longifolia (Tongkat Ali) in Malaysia (Perak and Pahang). Journal of Chromatography B Analytical Technologies in the Biomedical and Life Sciences 879(32): 3909-3919.

Danial, M., Keng, C.L., Alwi, S.S.R.S. \& Subramaniam, S 2011. Seed histology of recalcitrant Eurycoma longifolia plants during germination and its beneficial attribute for hairy roots production. Journal of Medicinal Plants Research 5(1): 93-98

De Klerk, G.J. \& Ter Brugge, J. 2011 . Micropropagation of dahlia in static liquid medium using slow-release tools of medium ingredients. Scientia Horticulturae 127(4): 542-547.

Etienne, H. \& Berthouly, M. 2002. Temporary immersion systems in plant micropropagation. Plant Cell, Tissue and Organ Culture 69: 215-231.

Gatica-Arias, A. \& Weber, G. 2013. Genetic transformation of hop (Humulus lupulus L.cv. Tettnanger) by particle bombardment and plant regeneration using a temporary immersion system. In Vitro Cellular \& Developmental Biology - Plant 49(6): 656-664.

Guan, H. \& De Klerk, G.J. 2000. Stem segments of apple microcuttings take up auxin predominantly via the cut surface and not via the epidermal surface. Scientia Horticulturae 86(1): 23-32.

Hassan, N.H., Abdullah, R., Kiong, L.S., Ahmad, A.R., Abdullah, N., Zainudin, F., Ismail, H. \& Rahman, S.S.A. 2012. Micropropagation and production of eurycomanone, 9-methoxycanthin-6-one and canthin-6-one in roots of Eurycoma longifolia plantlets. African Journal of Biotechnology 11(26): 6818-6825.

Hajjouli, S., Chateauvieux, S., Teiten, M.H., Orlikova, B., Schumacher, M., Dicato, M., Choo, C.Y. \& Diederich, M. 2014. Eurycomanone and eurycomanol from Eurycoma longifolia Jack as regulators of signaling pathways involved in proliferation, cell death and inflammation. Molecules 19(9): 14649-14666.

Hernández, I., Cuenca, B., Carneros, E., Alonso-Blazquez, N., Ruiz, M., Celestino, C., Ocana, L., Alegre, J. \& Toribio, M. 2011. Application of plant regeneration of selected cork oak trees by somatic embryogenesis to implement multivarietal forestry for cork production. Tree and Forestry Science and Biotechnology 5(Special Issue 1): 19-26.

Hussein, S., Ibrahim, R., Kiong, A.L.P., Fadzillah, N.M. \& Daud, S.K. 2005. Micropropagation of Eurycoma longifolia Jack via formation of somatic embryogenesis. Asian Journal of Plant Sciences 4(5): 472-485. 
Jimenez, E., Perez, N., Feria, M. De., Barbon, R., Capote, A., Chavez, M., Quiala, E. \& Perez, J.C. 1999. Improved production of potato microtubers using a temporary immersion system. Plant Cell, Tissue and Organ Culture 59: 19-23.

Kavitha, N., Noordin, R., Chan, K.L. \& Sasidharan, S. 2012. In vitro anti-toxoplasma gondii activity of root extract/fractions of Eurycoma longifolia Jack. BMC Complementary and Alternative Medicine 12(1): 91.

Keng, C.L., Wei, A.S. \& Bhatt, A. 2010. Elicitation effect on cell biomass and production of alkaloids in cell suspension culture of the tropical tree Eurycoma longifolia. Research Journal of the Costa Rican Distance Education University 2(2): 239-244.

Keng, C.L., Sai, S.T. \& Teo, C.K.H. 2002.A preliminary study on the germination of Eurycoma longifolia Jack (Tongkat Ali) seeds. Pertanika Journal of Tropical Agricultural Science 25(1): 27-34.

Khari, N., Aisha, A.F.A. \& Ismail, Z. 2014. Reverse phase high performance liquid chromatography for the quantification of eurycomanone in Eurycoma longifolia Jack (Simaroubaceae) extracts and their commercial products. Tropical Journal of Pharmaceutical Research 13(5): 801-807.

Kuo, P.C., Damu, A.G., Lee, K.H. \& Wu, T.S. 2004. Cytotoxic and antimalarial constituents from the roots of Eurycoma longifolia. Bioorganic \& Medicinal Chemistry 12(3): 537 544.

Li, C.H., Liao, J.W., Liao, P.L., Huang, W.K., Tse, L.S., Lin, C.H., Kang, J.J. \& Cheng, Y.W. 2013. Evaluation of acute 13-week subchronic toxicity and genotoxicity of the powdered root of Tongkat Ali (Eurycoma longifolia Jack). Evidence-Based Complementary and Alternative Medicine 2013: Article ID. 102987.

Ling, A.P.K., Phua, G.A.T., Tee, C.S. \& Hussein, S. 2010. Optimization of protoplast isolation protocols from callus of Eurycoma longifolia. Journal of Medicinal Plants Research 4(17): 1778-1785.

Mallón, R., Covelo, P. \& Vieitez, A.M. 2011. Improving secondary embryogenesis in Quercus robur: Application of temporary immersion for mass propagation. Trees 26(3): 731-741.

Murashige, T. \& Skoog, F. 1962. A revised medium for rapid growth and bio assays with tobacco tissue cultures. Physiologia Plantarum 15: 473-497.

Niemenak, N., Saare-Surminski, K., Rohsius, C., Ndoumou, D.O. \& Lieberei, R. 2008. Regeneration of somatic embryos in Theobroma cacao L. in temporary immersion bioreactor and analyses of free amino acids in different tissues. Plant Cell Reports 27(4): 667-676.

Paek, K.Y., Chakrabarty, D. \& Hahn, E.J. 2005. Application of bioreactor systems for large scale production of horticultural and medicinal plants. Plant Cell, Tissue and Organ Culture 81(3): 287-300.

Panjaitan, R.G.P., Handharyani, E., Chairul \& Manalu, W. 2013. Hepatoprotective activity of Eurycoma longifolia Jack roots. Indian Journal of Traditional Knowledge 12(4): 225-230.

Pérez, M., Bueno, M.A., Escalona, M., Toorop, P., Rodríguez, R. \& Cañal, M.J. 2013. Temporary immersion systems (RITA $\left.{ }^{\circledR}\right)$ for the improvement of cork oak somatic embryogenic culture proliferation and somatic embryo production. Trees 27(5): 1277-1284.

Polzin, F., Sylvestre, I., Déchamp, E., Ilbert, P., Etienne, H. \& Engelmann, F. 2014. Effect of activated charcoal on multiplication of African yam (Dioscorea cayenensisrotundata) nodal segments using a temporary immersion bioreactor $\left(\right.$ RITA $\left.^{\circledR}\right)$. In Vitro Cellular \& Developmental Biology - Plant 50: 210-216.

Radhakrishnan, N. \& Safinar, I.I. 2015. Cosmetic potential of Southeast Asian herbs: An overview. Phytochemistry Reviews 14: 419-428.

Roels, S., Escalona, M., Cejas, I., Noceda, C., Rodriguez, R., Canal, M.J., Sandoval, J. \& Debergh, P. 2005. Optimization of plantain (Musa AAB) micropropagation by temporary immersion system. Plant Cell, Tissue and Organ Culture 82(1): 57-66

Schönherr, J. 2006. Characterization of aqueous pores in plant cuticles and permeation of ionic solutes. Journal of Experimental Botany 57(11): 2471-2491.

Talbott, S.M., Talbott, J.A., George, A. \& Pugh, M. 2013.Effect of Tongkat Ali on stress hormones and psychological mood state in moderately stressed subjects. Journal of the International Society of Sports Nutrition 10(1): 28.

Teisson, C. \& Alvard, D. 1999. In vitro production of potato microtubers in liquid medium using temporary immersion. Potato Research 42: 499-504.

Varghese, C.P., Ambrose, C., Jin, S.C., Lim, Y.J. \& Keisaban, T. 2013. Antioxidant and anti-inflammatory activity of Eurycoma longifolia Jack, a traditional medicinal plant in Malaysia. International Journal of Pharmaceutical Sciences and Nanotechnology 5(4): 1875-1878.

Watt, M.P. 2012. The status of temporary immersion system (TIS) technology for plant micropropagation. African Journal of Biotechnology 11(76): 14025-14035.

Wilken, D., Jiménez Gonzalez, E., Gerth, A., Gómez-Kosky, R., Schumann, A. \& Claus, D. 2014. Effect of immersion systems, lighting, and TIS designs on biomass increase in micropropagating banana (Musa spp. cv. "Grande naine" AAA). In Vitro Cellular \& Developmental Biology - Plant 50(5): 582-589.

Wong, P.F., Cheong, W.F., Shu, M.H., Teh, C.H., Chan, K.L. \& AbuBakar, S. 2012. Eurycomanone suppresses expression of lung cancer cell tumor markers, prohibitin, annexin 1 and endoplasmic reticulum protein 28 . Phytomedicine: International Journal of Phytotherapy and Phytopharmacology 19(2): 138-144.

Zakaria, Y., Rahmat, A., Pihie, A.H.L., Abdullah, N.R. \& Houghton, P.J. 2009. Eurycomanone induce apoptosis in HepG2 cells via up-regulation of p53. Cancer Cell International 9: 16.

Zawawi, D.D., Ja'afar, H., Zainuddin, R., Kari, R. \& Mohd, N.M. 2015. Thidiazuron induces high frequency direct somatic embryogenesis growth from cotyledon culture of Eurycoma longifolia. Sains Malaysiana 44(7): 913-920.

School of Agriculture Science and Biotechnology Faculty of Bioresources and Food Industry Universiti Sultan Zainal Abidin, Tembila Campus 22200 Besut, Terengganu Darul Iman

Malaysia

*Corresponding author; email: nadiawati@unisza.edu.my

Received: 6 March 2016

Accepted: 9 November 2016 